\title{
SOLAR DECATHLON HÁZ AUTOMATIZÁLÁSI RENDSZERÉNEK FEJLESZTÉSE
}

\author{
Tóth József \\ MSc hallgató, Miskolci Egyetem, Automatizálás és Infokommunikációs Intézet \\ 3515 Miskolc, Miskolc-Egyetemváros, e-mail: toth.jozsef@uni-miskolc.hu
}

\begin{abstract}
Absztrakt
A Solar Decathlon egy nemzetközi verseny, melynek központi célja a megújuló energiák és innovatív épitészeti megoldások népszerüsitése. A versenyen a csapatok ezen szempontokat figyelembe véve épitik meg saját házukat. A Miskolci Egyetem csapata egy olyan házat épitett, amelyben jelentős szerepet kapnak a lakásautomatizálási, illetve intelligens rendszerek. A rendszer fó feladata a világitás vezérlés, fütési, illetve hütési vezérlés, valamint a szellöztetés vezérlése. A rendszer célja az, hogy egy olyan koncepciót mutasson be, amely a késöbbiekben potenciális felhasználók számára bemutatja, hogy ezek a rendszerek nem csak a kényelmi szempontokat vesznek figyelembe, hanem az energiahatékonyság is jelentös szerepet kap.
\end{abstract}

Kulcsszavak: Solar Decathlon, okosotthon, lakásautomatizálás, energiahatékonyság, épületgépészet

\begin{abstract}
The Solar Decathlon is a nationwide competition with the main goal of publicize the use of renewable energies and innovative construction solutions. During the competition, teams must build their houses according to these guidelines. The team of the University of Miskolc built a house where using of home automation and intelligent systems is widely applied. The main task of the system is to control illumination, heating and cooling elements and ventilation. The goal of this system is to introduce a conception which shows the potential clients how such system could be the benefit for one's comfort but also the energy efficiency has a mayor point.
\end{abstract}

Keywords: Solar Decathlon, smart home, home automation, energy efficiency, building engineering

\section{Bevezetés}

Az idei, 2019-es Solar Decathlon versenyen a Miskolci Egyetem a Pécsi Tudományegyetemmel, illetve az algír blidai egyetemmel közösen vett részt. A pécsi, illetve a blidai egyetem fő feladata a belső és külső építészet, illetve az épületgépészet tervezése és kivitelezése volt, a miskolci csapat feladata pedig a villamos hálózat, szenzor telepítés, illetve a lakásautomatizálás megvalósítása volt. A csapat egy könnyü szerkezetes házat épített, amely célja, hogy bemutassa milyen módon lehet felújítani a Magyarországon legnagyobb számban megtalálható ún. kockaházakat. A ház tervezése során fontos szempont volt a környezetbarát anyagok felhasználása, illetve az energiahatékonyság. Az anyagfelhasználást tekintve a ház szerkezete fából, különböző höszigetelő anyagokból, illetve ún. vályogrostlapból készült. További érdekessége a háznak, hogy a közepén megtalálható egy ún. ventúri torony. 


\section{Irodalomkutatás}

Az okos otthon elnevezés az angol „smart home” kifejezésből származik. Azt a házat tekintjük okos otthonnak, hogy monitorozza a körülményeket, a változások alapján képes beavatkozni és reagálni. Olyan épületautomatizálási megoldásokat alkalmaznak, amely egy fejlett központi egységgel rendelkezik, és ez távolról, más eszközökről is vezérelhető, és automatikus beavatkozásra képes. Ezeket a megoldásokat nem csak családi, vagy lakóház lehet, hanem ipari csarnokok, irodaházak, mezőgazdasági rendszerek stb. A központi egység gyüjti a különböző szenzorok adatait, mint a hőmérséklet, páratartalom, mozgásérzékelők stb. Majd ezen adatok alapján, és a felhasználói igények alapján avatkozik be. Egy épületben a következő rendszereknél van lehetőség automatizálásra [1].

- Fütés

- Hütés

- Árnyékolás technika

- Világítás

- Szellőztetés

- Motorok, ajtók, ablakok

- Szórakoztató elektronika

A vezérléshez szükséges a már korábban említett szenzorok adatai. Ezek a szenzorok a következök lehetnek.

- Hömérséklet

- Páratartalom

- Gázszenzorok

- Fényszenzorok

- Mozgásérzékelő, PIR szenzor

- Hang, zaj, akár beszédfelismerés

- Folyadék, áramlás

- Szélerősség, eső, nedvesség

- Végállásérzékelők, ablaknyitó, szögelfordulás mérő szenzorok

- NFC

Ahhoz, hogy a központi egység a szenzorok adatait feldolgozva, képes legyen beavatkozásra, különböző beavatkozók, ún. aktuátorok kellenek. Az aktuátorok a következők lehetnek.

- Relék

- Dimmerek

- Infravörös adók

- IP eszközök vezérlése

A szenzorokat és beavatkozókat felhasználva már automatizálható egy épület. A szenzorok adatait feldolgozva a központi rendszer elvégzi a megfelelő beavatkozásokat. Fontos, hogy ezen beavatkozások mindig a felhasználó igényei szerint történjenek. A felhasználói igényeket lehessen okoseszközökröl, vagy számítógépről állítani, viszont az okos otthonok fö célja az, hogy a felhasználó úgy élvezze annak előnyeit, hogy minél kevesebbszer avatkozik be a rendszer müködésébe [1].

\section{3. Épületgépészet}

A ház tervezése és építése során több épületgépészeti megoldás lett felhasználva. Az épületgépészet elengedhetetlen ahhoz, hogy a ház megfeleljen az okosotthon kritériumainak, és megfelelő komfort kialakítására alkalmas legyen. A komfort érzethez hozzájáruló épületgépészeti megoldások többek 
között a hütés, és fütési rendszerek, vizes rendszer és melegvíz előállító berendezések. A házban padlóilletve mennyezet fütés és hủtési rendszer, illetve fan coil található, amelyek feladata a megfelelö beltéri hőmérséklet előállítása.

\subsection{Padló, mennyezet hütés-fütés}

A házban megtalálható külön padló, illetve mennyezet fütés és hütési lehetőség. Ennek a megvalósításához gipszkarton hütő-fütő panelt alkalmaztunk. Ennek az az érdekessége, hogy a gipszkartonba egy csőrendszert építettek, amely rácsatlakozik a fütési, illetve hütési körre. Ezáltal a padlóban, illetve a mennyezeten elhelyezett gipszkartonok csőrendszerében keringő víz hőmérsékletének szabályozásával állíthatjuk a szobák hőmérsékletét. A gipszkartonok csövei egy ún. osztó-gyüjtőn keresztül csatlakoznak a fóágra. Az osztó-gyüjtőkön pedig elektronikusan vezérelhető szelepek vannak. Ezek a szelepek csatlakoznak az automatizálási rendszerre.

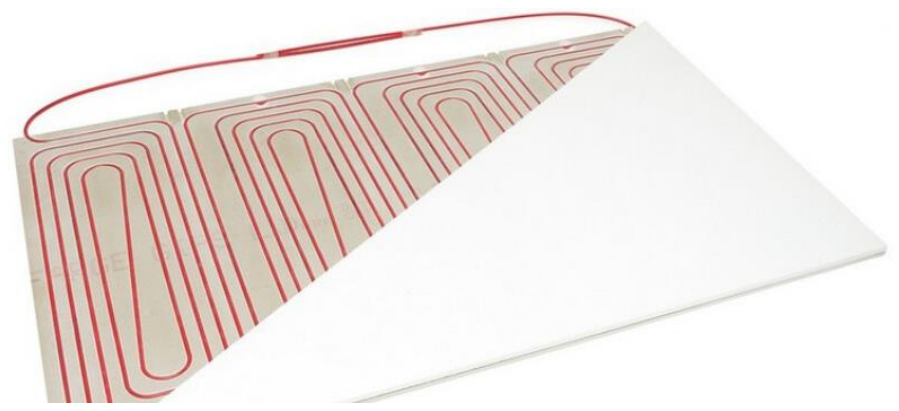

1. ábra. Gipszkartonba épitett csővezeték [2]

A házban padlófütés és hütés két helyiségben található, mégpedig a konyha és vele egybeépített nappaliban, illetve a hálószobában. Mennyezet fütés és hütés pedig csak a hálószobában található.

\subsection{Fan-coil}

A házba továbbá beépítésre került egy fan coil. Ennek feladata a szellőztetés, illetve fütés és hütés elösegítése. A fan coil belsejében egy lamellás höcserélö felület található. Ez a felület kellően nagy ahhoz, hogy nagy hőleadó felületet biztosítson. A lamellás hőleadó felületen keresztül átáramoltatott hideg vagy melegvíz által leadott hőt egy ventilátor továbbítja a levegős csőrendszerbe. Ezáltal könnyedén megoldható a hütési vagy fütési igény kielégítése. Ezen felül a csőrendszerbe kültéri friss levegöt is képes áramoltatni [3].

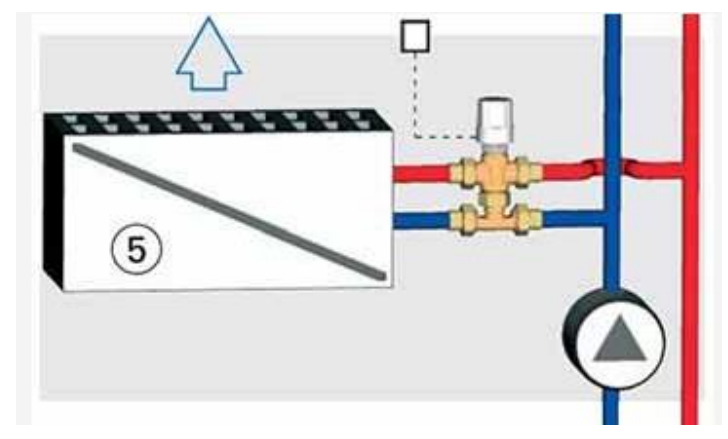

2. ábra. Fan-coil müködése [3] 


\subsection{Vizes rendszer}

A korábbi fejezetekben említett épületgépészeti rendszerekhez szükség van egy olyan rendszerre, amely a megfelelő nyomású, és hőmérsékletű vizet állítja elö. A verseny során a Vaillant cég biztosította ezt a rendszert. A rendszerhez több különbözö elem tartozik, mint pl fali légkezelő egység, kültéri hőszivattyú, beltéri egységek, puffer tartályok. Ez a rendszer szolgáltatja a rendszerek vizét, illetve a használati melegvizet. Az általunk fejlesztett automatizálási rendszer ennek a víznek a hőmérsékletét és mennyiségét szabályozza. A következő részben a megfelelő épületgépészeti rendszerek automatizálásának megvalósítását fogom bemutatni.

\subsection{Ventúri torony}

A ház közepén egy ún. ventúri torony található. A torony feladata a ház energiahatékony szellőztetésének biztosítása. Mivel a ház könnyüszerkezetes, így nem betonalapokon nyugszik. Ez azt jelenti, hogy a ház alatt, a talajhoz közel nagy légtömeg található. Továbbá a házon különböző szellőző nyílások vannak, továbbá a ventúri torony tetején nyitható lamellák találhatók. A lamellák nyitásával és zárásával a házban egy természetes szellőztetés jön létre, amely a benti meleg levegöt felül kiengedi, alulról pedig friss levegőt szív be, így cserélve a ház belső légtömegét. Az automatizálási rendszer ezeknek a lamelláknak a nyitását, illetve zárását végzi.

\section{Villamos- és automatizálási rendszer}

Az automatizálási rendszer központi egysége egy Loxone gyártmányú eszköz. Az eszközön több különböző periféria megtalálható, többek között relé kontaktok, digitális bemenetek, analóg be- illetve kimenetek. Ezen bemeneti és kimeneti csatlakozók segítségével különböző vezérlési és szabályozási feladatokat képes ellátni az eszköz. A müködéséhez egy 24 V DC feszültségü tápegységre van szükség. Mind a tápegység, mind az eszköz és egyéb kiegészítő modulok kalapsínre szerelhetők. A Loxone miniserver eszközéhez több különböző bővítőmodult köthetünk CAN buszon keresztül. A háznál alkalmazott rendszernél a TwinCable cég által fejlesztett AABoard relé modul és egy AACombo kiegészítő modul tartozik. A relé modul a 2x24 relé kontaktust tartalmaz, az AACombo kiegészítő modul pedig $2 \times 12$ további relé kontaktust, KNX busz csatlakozást, OneWire csatlakozást, RS485 kommunikáció csatlakozást, LED vezérlő kimenetet, illetve 14 digitális bemenetet tartalmaz. A továbbiakban a különbözö eszközök által ellátott feladatokat fogom bemutatni [4,5].

\subsection{Loxone Miniserver}

A Loxone miniserver az automatizálási rendszer központi része. Ennek a perifériáit már egy korábbi fejezetben bemutattam. A vezérlés szoftveresen kerül megírásra. Ehhez a Loxone saját fejlesztésü szoftverét használtuk. A szoftver egyik elönye, hogy magyar nyelvü, és a gyakori épületgépészeti megoldások előre programozott ún. funkció blokkokban találhatók. Így a programozás jelentösen egyszerüsödik, mivel csak a megfelelő bemenetet, illetve kimenetet kell rákötni a megfelelő blokkra. A szoftver megírása után csak fel kell tölteni a programot az eszközre, valamint be kell kötni a megfelelö vezérelni kívánt eszközök vezetékeit. A miniserver jelen esetben a padló és mennyezet fütési és hütési köreinek osztó gyüjtő szelepeit vezérli, valamint a ventúri torony tetején található lamellákat. A miniszerver a belső hőmérséklet, valamint a felhasználói igény szerint szabályozza ezeket a szelepeket. A 3. ábra mutatja a miniserver bekötési rajzát. 


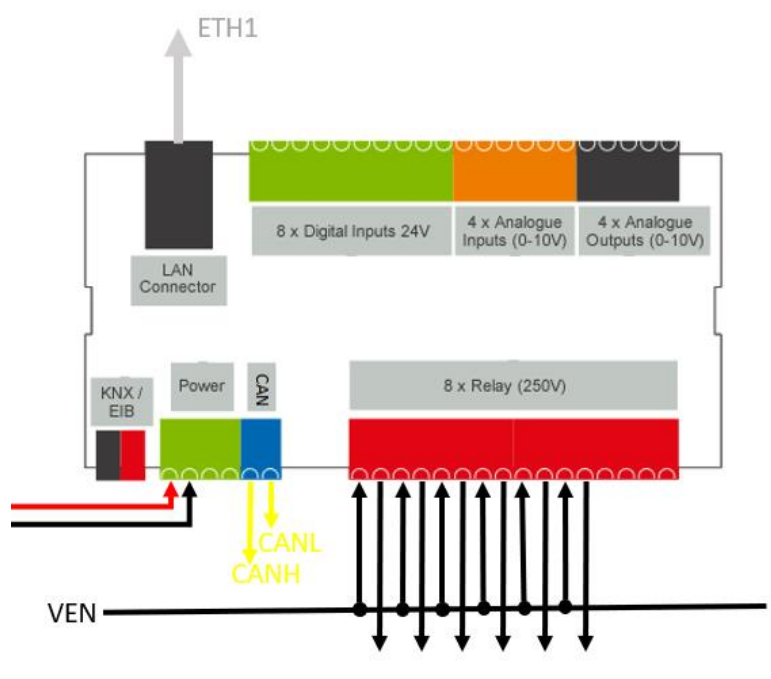

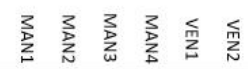

\section{3. ábra. Loxone Miniserver bekötési rajza [4]}

A szoftver további nagy előnye, hogy a megírt programhoz automatikusan generál egy webes felületet. A webes felületen láthatóvá válnak a be, illetve kimenetek, létrehozhatók virtuális bemenetek, illetve analóg értékeket is megjelenít, mint pl a hőmérséklet. Így, ha a Loxone eszközeinket egy okos eszközről elérhető szerverre kötjük, akkor ezen okoseszközök segítségével a felhasználó beavatkozhat a szabályozásba.

\subsection{Kiegészítő modulok}

A kiegészítő modul CAN buszon keresztül kommunikál a miniserver eszközzel. A programozása ugyanazona a felületen történik. Ez a modul szintén több feladatot lát el. Digitális bemenetein kapcsolók jeleit fogadja. Ezek a kapcsolók kültéri, illetve beltéri világítást kapcsolnak és dimmelnek. Beltéren LED szalagok kerültek elhelyezésre. Ezeket okoseszközökkel könnyedén vezérelhetjük. A kültéri világítást a relés kiegészítő modul kapcsolja. A LED világításhoz ún. LED vezérlő egység szükséges. Ezt a Combo eszköz RS485 kommunikációval vezérli. A bekötés a következő ábrán látható (4. ábra).

A Combo modul további feladata a Vaillant rendszer szekunder oldali víz körének vezérlése. Az elöremenő víz három körre lett osztva. Ezeken keverőszelep található, amely segítségével a hideg és melegvizet engedi egy csőbe, ezzel a kívánt hőmérsékletet elérve. A hőmérsékleti adatokat a csőre szerelt onewire hőmérők adatai adják. A keverőszelepek mozgatása után egy szivattyú vezérlése szükséges. Ezen eszközök a fenti képen látható Pump és VAL elnevezésü kimenetekre csatlakoznak. Továbbá a korábbi fejezetekben említett fan-coil vezérlését is a relé modul valósítja meg. A fan-coil három fokozaton képes múködni, min, mid és max. Ezek segítségével állítható az, hogy milyen erősséggel fújja a levegőt az eszköz. Ezeknek a bekötése az 5. ábrán látható. 

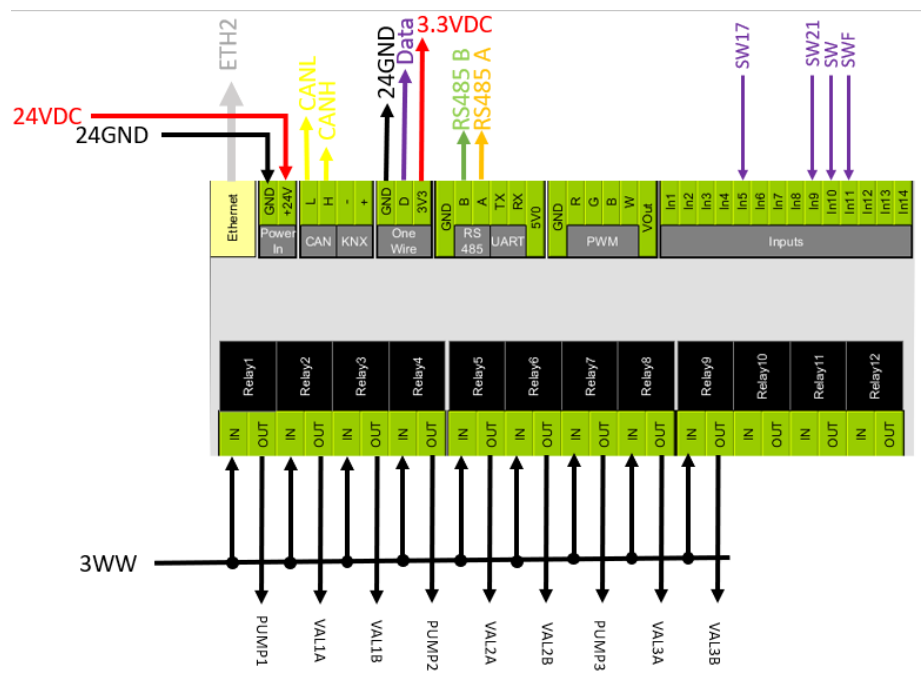

4. ábra. AACombo kiegészitö modul [5]

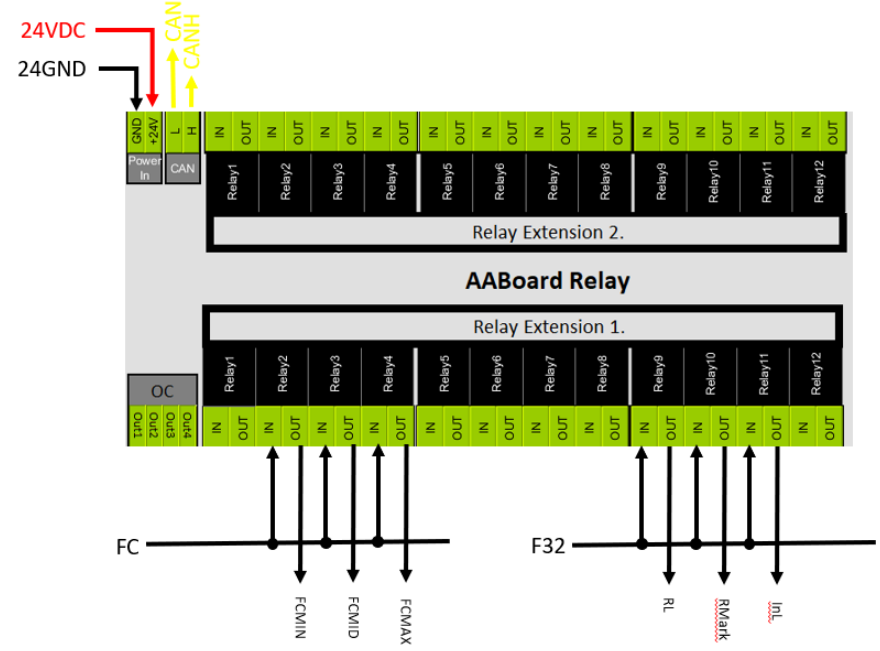

5. ábra. AABoard relé kiegészitö modul

A csapatban az én feladatom volt a bemutatott eszközök bekötése. A bekötés első lépéseként megfelelő elhelyezést kell kialakítani a kapcsolószekrényben. A Loxone modulok kerültek a kapcsolószekrény felső részébe, majd ezek alatt helyezkedtek el a különböző kiegészítő egységek, tápegységek, valamint sorkapcsok. A sorkapcsok a szekrény aljában kaptak helyet, annak érdekében, hogy a bekötés egyszerübb legyen. Fontos volt, hogy minden sorkapcsot a kapcsolási rajz alapján egy jelölővel láttam el. Az elkészült kapcsolószekrény a 6. ábrán látható. 


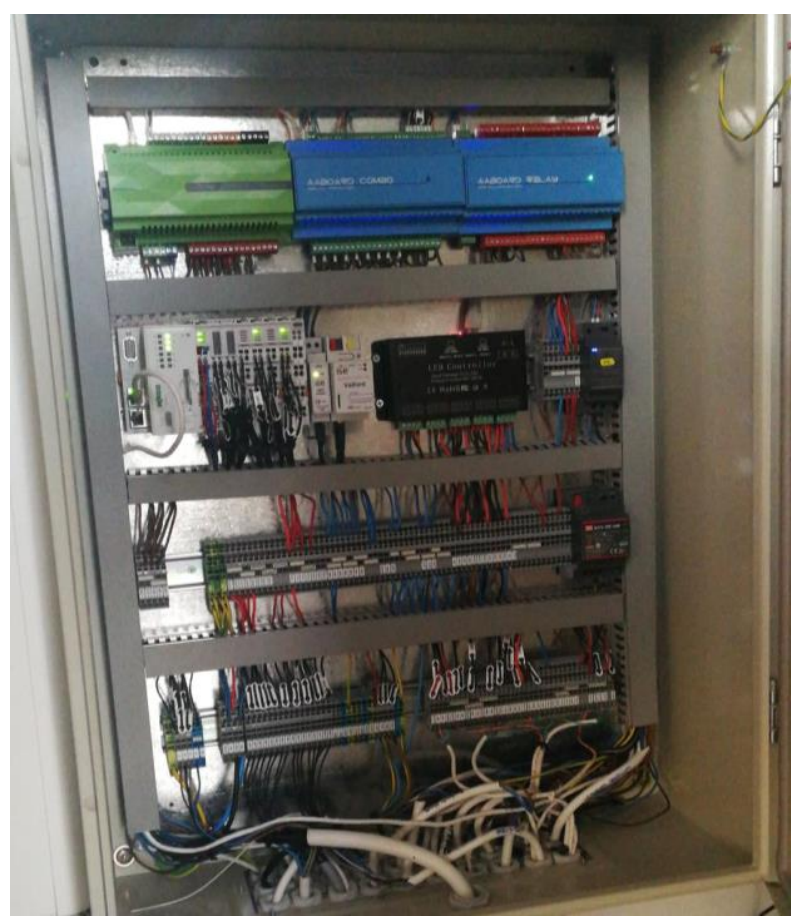

\section{6. ábra. Automatizálási rendszer}

Általánosan elmondható, hogy az automatizálási rendszer megfelelően müködött a verseny alatt. A világítás, a fütés és hütési rendszer, illetve a ventúri torony lamellái is könnyedén állítható okoseszköz, és hagyományos kapcsolók segítségével is. A megépített ház a következő képen látható (7. ábra).

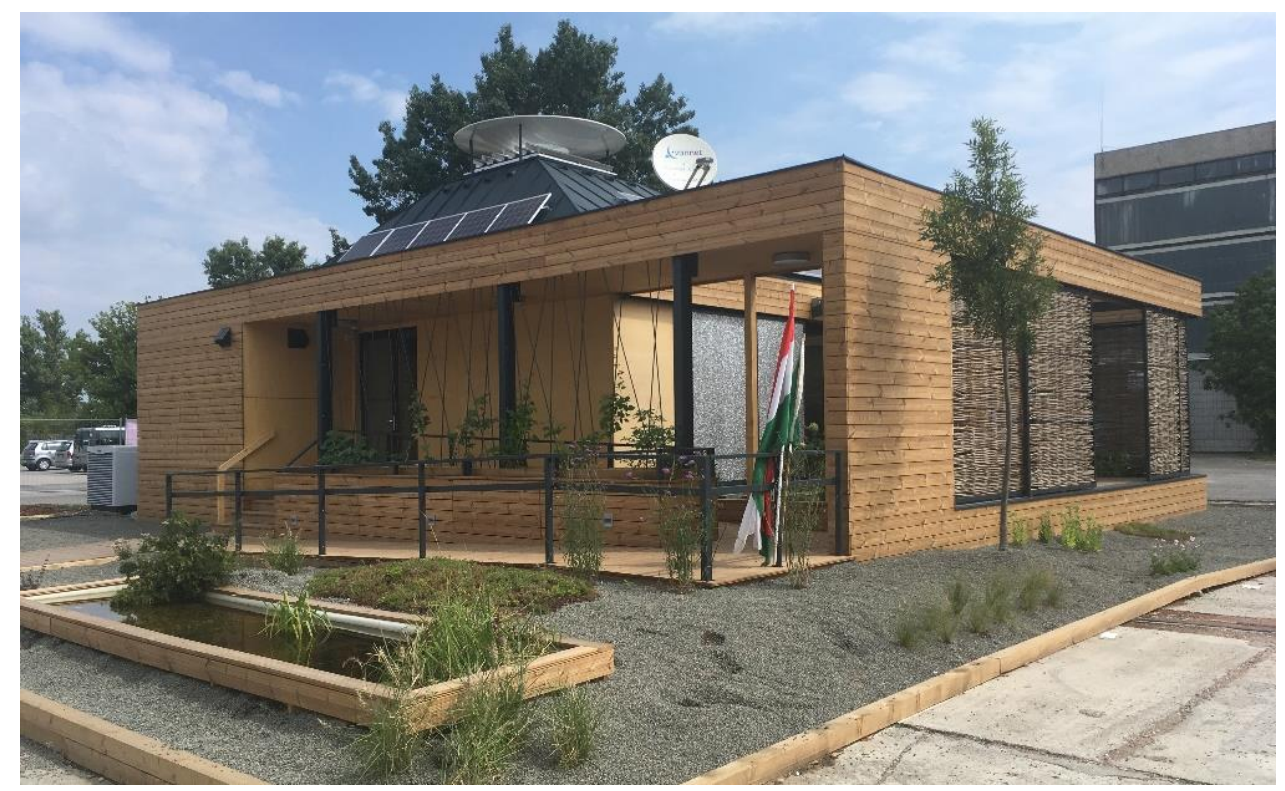

7. ábra. Hungarian Nest+ ház 


\section{5. Összefoglalás}

Az elkészült ház automatizálási rendszere a beüzemelést követően megfelelően müködött. A nyári látogatási időszakban a házban mindig kellemes és komfortos hőmérséklet volt, így elmondható, hogy ezek a rendszerek kiválóan alkalmazhatók lakás és épületautomatizálási megoldásokhoz. Általános tapasztalat az, hogy az okosház rendszerek egyre elterjedtebbek, és ezen eszközök gyártói is törekednek olyan megoldásokat fejleszteni, amivel egyre szélesebb körben elérhetők lesznek az emberek számára ezek a rendszerek. A verseny során csak az épületgépészet, és világítási rendszer került bele az okos rendszerbe, de ezek a rendszerek számos további funkciót képesek ellátni. A továbbiakban ezeknek a fejlesztésére és tesztelésére is van lehetőség.

\section{Köszönetnyilvánítás}

A cikkben ismertetett kutató munka az EFOP-3.6.1-16- 00011 jelü „Fiatalodó és Megújuló Egyetem Innovatív Tudásváros - a Miskolci Egyetem intelligens szakosodást szolgálóintézményi fejlesztése" projekt részeként - a Széchenyi 2020 keretében -az Európai Unió támogatásával, az Európai Szociális Alap társfinanszírozásával valósul meg.

\section{Irodalom}

[1] Okosházmester, 2015. [Online]. Available: https://www.okoshazmester.hu/mitol-okos-azokosotthon. [Hozzáférés dátuma: 1010 2019].

[2] Markos, A. Zs.: Gépész Blog, Gépész Holding, 1301 2017. [Online]. Available: https://gepesz.hu/blog/details.php?hir=61\&Rehau+mennyezetf. [Hozzáférés dátuma: $10 \quad 10$ 2019].

[3] Varga, Cs.: Rifeng-hőszivattyú, SNAP hőszivattyú, [Online]. Available: https://www.rifenghoszivattyu.hu/fan-coil-futo-huto. [Hozzáférés dátuma: 1012 2019].

[4] Loxone, Loxone, [Online]. Available: https://www.loxone.com/enen/kb/miniserver-technicalinfo/. [Hozzáférés dátuma: 2311 2019].

[5] Házveled, TwinCable, [Online]. Available: http://hazveled.hu/aaboard/combo/. [Hozzáférés dátuma: 1511 2019]. 